\title{
Delusional Disorder: Molecular Genetic Evidence for Dopamine Psychosis
}

\author{
Kiyoshi Morimoto, M.D., Ph.D., Ryosuke Miyatake, M.D., Ph.D., Mitsuo Nakamura, M.D., Ph.D.,
} Takemi Watanabe, M.D., Ph.D., Toru Hirao, M.D., Ph.D., and Hiroshi Suwaki, M.D., Ph.D.

Since delusional disorder is characterized by monosymptomatic paranoid symptoms, it can be a good clinical model for investigating the dopaminergic mechanism responsible for paranoid symptoms. We examined neuroleptic responses, plasma homovanillic acid ( $p H V A$ ) and genes of the dopamine receptor (DR) and its synthesizing enzyme (tyrosine hydroxylase: $T H$ ) in patients with delusional disorder and compared them with those of schizophrenic patients and healthy controls. Results: (1) A relatively small dose of haloperidol was more effective for delusional disorder than for schizophrenia. (2) The pretreatment level of $\mathrm{pHVA}$ was higher in patients with persecution-type, but not in those with jealousy-type delusional disorder, compared with age- and sex-matched controls. This increased $p H V A$ level was decreased eight weeks after successful haloperidol treatment. (3) The genotype frequency of the DRD2 gene Ser311Cys was significantly higher in patients with persecution-type delusional disorder (21\%), compared with schizophrenic patients (6\%) or controls (6\%). (4) Patients homozygous for the DRD3 gene Ser9Ser had higher pretreatment levels of $\mathrm{pHVA}$ than those heterozygous for Ser9Gly. (v) A significant positive correlation was found between the polymorphic $(\mathrm{TCAT})_{n}$ repeat in the first intron of the $\mathrm{TH}$ gene and pretreatment levels of $p H V A$ in delusional disorder. We suggest that delusional disorder, especially the persecution-type, includes a "dopamine psychosis," and that polymorphism of the DRD2, DRD3 and/or TH gene is part of the genetic basis underlying the hyperdopaminergic state that produces paranoid symptoms. Further studies on a large sample size are required.

[Neuropsychopharmacology 26:794-801, 2002]

(C) 2002 American College of Neuropsychopharmacology. Published by Elsevier Science Inc.
KEY WORDS: Delusional disorder; Dopamine psychosis; pHVA; Polymorphism; DRD2 Ser311Cys; DRD3 Ser9Gly;

Although the neurobiological mechanism underlying schizophrenia has been investigated extensively during the past few decades, its biochemical and molecular eti-

From the Department of Neuropsychiatry, Faculty of Medicine, Kagawa Medical University, Kagawa, Japan.

Address correspondence to: Kiyoshi Morimoto, M.D., Ph.D., Department of Neuropsychiatry, Faculty of Medicine, Kagawa Medical University, 1750-1 Ikenobe, Miki-cho, Kita-gun, 761-0793 Japan, Tel: +81-87-891-2167, fax: +81-87-891-2168, E-mail: neuropsy @kms.ac.jp

Received August 2, 2001; revised October 29, 2001; accepted November 2, 2001.

Online publication: $11 / 28 / 01$ at www.acnp.org/citations/ Npp 112801213. ology remain unclear. The long-standing "dopamine hypothesis" of schizophrenia (Carlsson 1988) is partly supported by the action of neuroleptics, which block dopamine receptors (DRs) and improve paranoid symptoms, such as delusion and hallucination (Seeman et al. 1976). It has further been supported by indirect evidence that repeated administration of dopamine agonists (e.g. amphetamine and cocaine) results in the development of paranoid symptoms in humans (Ellinwood 1976; Sato et al. 1992) and abnormal behavior ("behavioral sensitization") in animals (Kalivas 1993). In schizophrenic patients, dopamine agonists aggravate paranoid symptoms (Janowski and Davis 1976; Lieberman et al. 1987); this may be the result of an aberrant increase in dopamine release (Laruelle et al. 1996; Breier et al. 1997). However, many clinical studies on plasma 
and cerebral spinal fluid (CSF), DR imaging, and postmortem brain or DR genes have failed to obtain direct hyperdopaminergic evidence, or if such evidence has been obtained, the results have been contradictory (Davis et al. 1991; Willner 1997; Laruelle 1998; Zakzanis et al. 1998; Harrison 1999; Soares and Innis 1999; see also Discussion).

One of the most important reasons for these complex results may be etiological heterogeneity of the disorder, since there is a considerable variety of clinical features of schizophrenia, including symptoms, neuroleptic response and long-term prognosis, between the patients. To evaluate and categorize the heterogeneity clinically, some biology-based classifications have been proposed, for example "type I and type II syndromes" (Crow 1980), "3 syndromes" (Liddle 1987), and "deficit and non-deficit forms" (Carpenter et al. 1988).

Another methodology that may allow us to break through the heterogeneity and clarify the role of dopamine systems in psychosis is to select a psychiatric disorder with only one target schizophrenic symptom. While paranoid symptoms are commonly seen in various psychiatric disorders, as known "paranoid spectrum" (Fujinawa 1981), delusional disorder, a psychosis previously called "paraphrenia" (Kraepelin 1909; Roth 1987), is characterized by mono-symptomatic paranoid symptoms without other schizophrenic symptoms. In the ICD-10 diagnostic criteria (WHO 1992), delusional disorder is diagnosed when: (1) delusions constitute the only, or the most conspicuous, clinical characteristic; (2) it cannot be classified as organic, schizophrenic, or affective disorder; and (3) affect, speech, and behavior are normal. Thus, delusional disorder can be a good clinical model for investigating the molecular genetic mechanisms for paranoid symptoms.

In the present study, we hypothesized that a hyperdopaminergic state in the brain is responsible for producing paranoid symptoms. To test this hypothesis, we compared neuroleptic responses between patients with delusional disorder and schizophrenia, measured plasma levels of homovanillic acid (pHVA), a dopamine metabolite and clinical marker of dopamine metabolism, in patients with delusional disorder before and after neuroleptic treatment, and analyzed the polymorphism of DR and its synthesizing enzyme gene.

\section{METHODS}

\section{Neuroleptic Response of Delusional Disorder}

Subjects. Eleven patients with delusional disorder classified according to ICD-10, who were admitted to our psychiatric ward, were studied. All patients presented the first delusional episode without previous neuroleptic medication. The average (mean \pm S.E.M.) age (and age at onset) was $57.5 \pm 2.2$ years $(54.6 \pm 2.2$ years) and the male/female ratio was $1 / 10$. Neuroleptic responses, including effective neuroleptic dose (haloperidol equivalent, mg/day), duration of admission, and outcome at discharge (complete/incomplete remission) were examined. To evaluate social function, the Global Assessment of Functioning (GAF; DSM-IV (American Psychiatric Association 1994)) score was used. In addition, we compared the neuroleptic responses of 15 patients with schizophrenia, who presented their first psychotic episode and were admitted during the same period, with those of the patients with delusional disorder. The average of age (at onset) of these schizophrenic patients was $25.1 \pm 1.4$ years $(22.7 \pm 1.3$ years), the male/female ratio was $7 / 8$, and the ICD-10 subtypes included 6 paranoid, 6 undifferentiated, 2 hebephrenic, and 1 catatonic type.

\section{pHVA in Delusional Disorder}

Subjects. To investigate brain dopamine function, pHVA levels were measured in patients with delusional disorder and compared with those of age- and sex-matched controls. Thirteen neuroleptic-naive patients with delusional disorder (age at onset was 48.4 years; male/female ratio was $4 / 9$ ) were subjects in our inpatient and outpatient clinics. The subtypes involved were: nine persecution-type and four jealousy-type. Written informed consent to participate this study was obtained from all patients. Blood for pHVA was drawn between 9:00 A.M. and 11:00 A.M. before starting neuroleptic treatment. The Brief Psychiatric Rating Scale (BPRS) was used to evaluate the level of delusional psychopathology in each patient. In addition to the pretreatment examination, in eight patients, pHVA and BPRS scores were measured eight weeks after neuroleptic treatment with a small dose of haloperidol (average $2.7 \mathrm{mg}$ /day).

Measurement of pHVA. pHVA concentrations were determined by high-performance liquid chromatography using electrochemical detection analysis (Chang et al. 1983). The interassay coefficients of variance were 1.2 and $1.7 \%$ for concentrations of 20 and $100 \mathrm{pmol} / \mathrm{ml}$, respectively.

\section{The DR and Tyrosine Hydroxylase Gene in Delusional Disorder}

Subjects. To investigate the possible genetic basis underlying the hyperfunction of dopamine systems in delusional disorder, we analyzed the polymorphism of genes for DRD2 and DRD3 and their synthesizing enzyme tyrosine hydroxylase (TH). Twenty-three patients with delusional disorder, 48 patients with schizophrenia, and 48 normal controls were studied. Delusional 
patients included the subjects for our pHVA study. The age at onset was 52.3 years, male/female ratio was $4 / 19$, and the subtypes were 19 persecution-type and 4 jealousy-type. Written informed consent to participate in the study was obtained from all patients and normal control subjects.

\section{Genotyping}

We analyzed polymorphisms of Ser311Cys in the DRD2 gene (Arinami et al. 1994), Ser9Gly in the DRD3 gene (Crocq et al. 1992), and variable number of tandem repeat (VNTR) in the first intron of TH gene (Wei et al. 1995). Genomic DNA was extracted from the subjects' peripheral blood according to a standard method. Polymerase chain reaction (PCR) amplification was performed using $50 \mathrm{ng}$ of DNA, $250 \mu \mathrm{M}$ dNTP, $1.5 \mathrm{mM}$ $\mathrm{MgCl} 2,5.0 \mu \mathrm{l}$ of $\times 10 \mathrm{LA}$ buffer (TaKaRa), 0.5 units of LA Taq polymerase (TaKaRa), and $0.1 \mu \mathrm{M}$ each of the primer, which have been described previously (Arinami et al. 1994; Crocq et al. 1992; Wei et al. 1995) in a total volume of $50 \mu \mathrm{l}$. Samples were amplified for an initial cycle of $1 \mathrm{~min}$ at $94^{\circ} \mathrm{C}$ followed by 35 cycles, each consisting of denaturing of $30 \mathrm{~s}$ at $94^{\circ} \mathrm{C}$, annealing of 30 $\mathrm{s}$ and extension of $1 \mathrm{~min}$ at $72^{\circ} \mathrm{C}$. Annealing temperatures were $65^{\circ} \mathrm{C}$ for Ser311Cys, $55^{\circ} \mathrm{C}$ for Ser9Gly and $57^{\circ} \mathrm{C}$ for (TCAT) $\mathrm{n}$ VNTR. For restriction fragment length polymorphism analysis of the Ser9Gly polymorphism, PCR products were digested with units of BalI (TaKaRa) and recommended buffer for at least $6 \mathrm{~h}$ at $37^{\circ} \mathrm{C}$. The electrophoresis was performed with $2 \%$ agarose gel for the Ser311Cys and Ser9Gly polymorphisms, and with $20 \%$ polyacrylamide gel for (TCAT) $)_{n}$ VNTR.

\section{RESULTS}

\section{Neuroleptic Response of Delusional Disorder}

The onset of delusional disorder appeared to be in middle age in all patients and was much later than for schizophre- nia. A clear gender difference was also seen in delusional disorder (female $>$ male). A relatively smaller dose of haloperidol $(4.7 \mathrm{mg} /$ day) was effective in diminishing completely delusional symptoms within a shorter period of administration (65 days) in delusional disorder as compared with schizophrenia ( $12.7 \mathrm{mg} /$ day, 104 days). At discharge, the GAF score was significantly higher in delusional disorder, which suggests a better prognosis (Table 1 ).

\section{pHVA in Delusional Disorder}

Pretreatment Level of $p H V A$. The pretreatment level of pHVA tended to be more elevated in delusional disorder than in normal control individuals (64.5 vs. 48.9 $\mathrm{pmol} / \mathrm{ml}, p<.1$, Figure 1) and it was correlated significantly to the delusion and hallucination BPRS score ( $\mathrm{r}=$ $0.44, p<.02$, Figure 2, Panel A). When the delusional patients were classified into the different subtypes, the persecution-type showed a higher level of pHVA (68.5 $\mathrm{pmol} / \mathrm{ml}, p<.05)$ than the controls, while the jealousytype did not (55.5 pmol/ml, Figure 1).

pHVA Level after Neuroleptic Treatment. Eight weeks after neuroleptic treatment with a small dose of haloperidol, the delusion and hallucination BPRS score improved markedly, and five out of eight patients went into complete remission. The level of pHVA also significantly decreased eight weeks after the successful neuroleptic treatment (Figure 2, Panel B).

\section{The DR and TH Gene in Delusional Disorder}

DRD2 Ser311Cys. The genotype frequency of DRD2 Ser311Cys was $17.4 \%$ in delusional disorder, $6.3 \%$ in schizophrenia, and $6.3 \%$ in control subjects (Table 2). There was a significantly higher incidence of Ser311Cys heterozygote among the persecution-type delusional patients $(21.1 \%, p<.05)$, compared with the controls; none of jealousy-type delusional patients exhibited this

Table 1. Neuroleptic Response in In-Patients with Delusional Disorder and Schizophrenia

\begin{tabular}{lcc}
\hline & $\begin{array}{c}\text { Delusional Disorder } \\
(\mathbf{N}=\mathbf{1 1})\end{array}$ & $\begin{array}{c}\text { Schizophrenia } \\
\mathbf{( N = 1 5 )}\end{array}$ \\
\hline Age & $57.5 \pm 2.2^{* * *}$ & $25.1 \pm 1.4$ \\
Onset & $54.6 \pm 2.2^{* * *}$ & $22.7 \pm 1.3$ \\
Male/Female & $1 / 10$ & $7 / 8$ \\
Effective NLP Dose & & \\
$\quad$ (HPD mg/day) & $4.7 \pm 0.9^{* *}$ & $12.7 \pm 1.4$ \\
Administration (Days) & $51.2 \pm 6.3^{*}$ & $98.7 \pm 16.8$ \\
Outcome (Complete/ & & \\
Incomplete Remission) & $11 / 0^{\#}$ & $9 / 6$ \\
GAF at Discharge & $76.8 \pm 2.3^{* *}$ & $65.6 \pm 2.3$ \\
\hline
\end{tabular}

NPL: Neuroleptics, HPD: Haloperidol, GAF: Global Assessment of Functioning

${ }^{*} \mathrm{p}<.05,{ }^{* *} \mathrm{p}<.01,{ }^{* * *} \mathrm{p}<.001$ (Student's t-test), ${ }^{*} \mathrm{p}<.05$ (Fisher's test) 


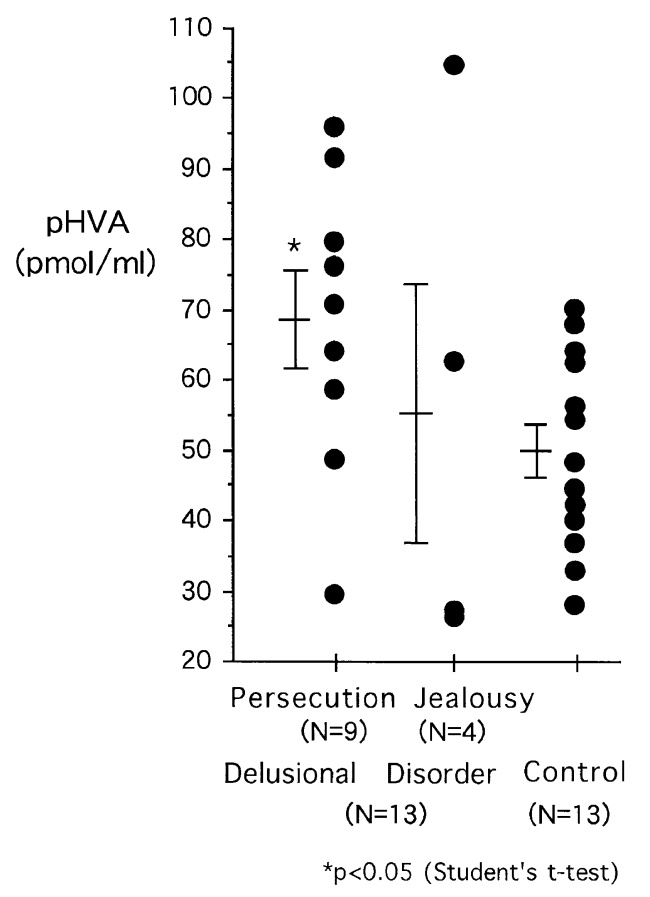

Figure 1. The pretreatment level of plasma homovanillic acid (pHVA) in patients with delusional disorder. pHVA was higher in persecution-type delusional patients, but not in those with jealousy-type, compared with age- and sexmatched controls.

genotype. The pretreatment level of pHVA tended to be higher in Ser311Cys patients $(77.8 \mathrm{pmol} / \mathrm{ml}, n=4)$ than in Ser311Ser patients ( $58.6 \mathrm{pmol} / \mathrm{ml}, n=9$; Table 3).

DRD3 Ser9Gly. The genotype frequency of the DRD3 Ser9Ser gene was $47.8 \%$ in delusional disorder $(52.6 \%$ in persecution-type and $25.0 \%$ in jealousy-type), $47.9 \%$ in schizophrenia, and $39.6 \%$ in control subjects (Table 2). Patients who were homozygous for the Ser9Ser had a higher pretreatment level of pHVA than those who were heterozygous (85.6 vs. $51.3 \mathrm{pmol} / \mathrm{ml}, p<.05$; Table 3 ).

TH VNTR. There was a significant positive correlation between the polymorphic (TCAT) $)_{n}$ repeat in the first intron of the TH gene and pretreatment level of pHVA in delusional disorder $(\mathrm{r}=0.62, p<.05)$. Patients with the $(\text { TCAT })_{8}$ or $(\text { TCAT })_{9}$ allele had higher levels of pHVA than those with (TCAT) $)_{6}$ or $(\mathrm{TCAT})_{7}(87.1 \mathrm{vs.} 47.9 \mathrm{pmol} / \mathrm{ml}$, $p<.02$; Table 4$)$.

\section{DISCUSSION}

Delusional disorder has some clinical characteristics that are quite different from schizophrenia, such as later onset, gender difference (female $>$ male), lack of schizophrenic negative symptoms and preservation of social function. Furthermore, the delusional disorder patients responded well to treatment with haloperidol despite a rather low mean dose ( $4.7 \mathrm{mg} /$ day). Although firm conclusions cannot be drawn because of the lack of randomized dosage assignment, this does suggest that those subjects are rather responsive to treatment with dopamine-blocking agents (Pearlson et al. 1989, Munro and Mok 1995). These clinical and neuropharmacological features suggest that the brain mechanisms are not identical in these psychotic disorders, and it is hypothesized that it is primarily dopamine function that may be disturbed in delusional disorder.

In the present study, to obtain more direct evidence to confirm this hypothesis, pHVA was employed as a "state marker" of the disorder whereas polymorphism of the DR gene was used as a "trait marker."

\section{Hyperdopaminergic State Responsible for Paranoid State}

While a number of previous pHVA studies have failed to obtain consistent results with regard to schizophrenia, three main lines of evidence have been reported: (1) pHVA is correlated positively with the severity of psychotic symptoms (Davis et al. 1985; Pickar et al. 1986; Davidson and Davis 1988); (2) in good responders pHVA decreases along with neuroleptic treatment (Pickar et al. 1984; Pickar et al. 1986; Chang et al. 1988; Koreen et al. 1994; Nagaoka et al. 1997); and (3) pHVA is lower in deficit-type than in non-deficit-type (Davidson and Davis 1988; Ribeyre et al. 1994; Thibaut et al. 1998). From these findings, it seems that pHVA varies depending upon the subtype and course of schizophrenia, and it is also strongly influenced by neuroleptic treatment.

In contrast to these complicated results for pHVA, more consistent results have been observed in psychoses with a good prognosis, which is unrelated to their conventional diagnosis (Bowers et al. 1984; Bowers 1993; Garver et al. 1997; Ottong and Garver 1997). For example, Garver et al. (1997) have demonstrated recently that baseline pHVA is bimodally distributed in acute psychotic patients including those with schizophrenia, schizophreniform disorder and psychotic affective disorder, and that high-pHVA psychotic patients have a more rapid and complete neuroleptic response than lower-pHVA psychotics. They have suggested that the higher-pHVA psychosis is a dopamine psychosis that may have a familial origin.

Our pHVA study had some limitations. Time of blood sampling was not strictly controlled, and since out-patients were included in the study, a low monoamine diet was not available. However, our time-course study on pHVA before and after neuroleptic treatment must be reliable because of the repeated measurements taken in the same individual. Despite the limitations, our findings on pHVA in delusional disorder are in 

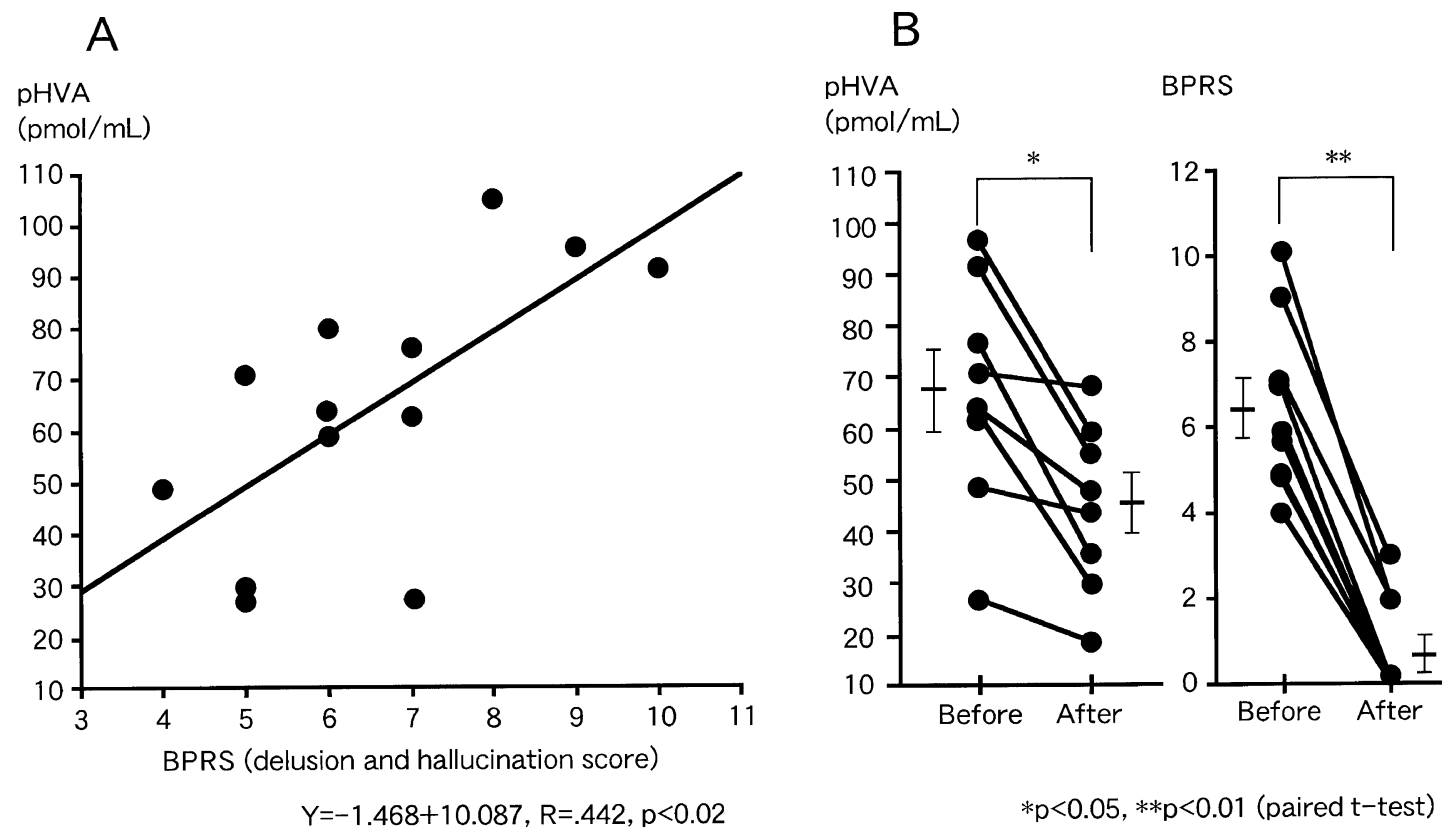

Figure 2. Relationship between the pretreatment level of pHVA and BPRS (A), and their changes after neuroleptic treatment (B) in delusional disorder. A: A significant positive correlation was found between the pHVA level and BPRS delusion and hallucination score. B: Eight weeks after treatment with a relatively small dose of haloperidol (average $2.7 \mathrm{mg} / \mathrm{day}$ ), the increased levels of pHVA and BPRS scores were reduced.

good agreement with Garver's results. In our study, pretreatment pHVA levels were elevated in persecution-type patients, positively correlated with the severity of paranoid symptoms, and normalized after successful neuroleptic treatment. In contrast, pHVA showed large variation, especially in jealousy-type delusional patients, suggesting heterogeneity in this diagnostic category (e.g., paraphrenia, paranoia and late-onset schizophrenia). It is concluded from our pHVA study that pHVA state-dependent changes in neuroleptic-naive delusional disorder and hyperfunction of the dopamine systems could be at least partly responsible for the brain mechanisms underlying its paranoid symptoms.

\section{Molecular Genetic Basis of Delusional Disorder}

Our molecular genetic analysis of delusional patients revealed the possible involvement of gene polymor-

Table 2. Genotype Frequency of Dopamine D2 and D3 Recepor Gene

\begin{tabular}{llcc}
\hline & & \multicolumn{2}{c}{ Genotype Frequency } \\
\cline { 3 - 4 } & & D2 Ser311Cys & D3 Ser9Ser \\
\hline Delusional Disorder & $\mathrm{N}=23$ & $17.4 \%$ & $47.8 \%$ \\
Persecution & $\mathrm{N}=19$ & $21.1 \% *$ & $52.6 \%$ \\
Jealousy & $\mathrm{N}=4$ & $0.0 \%$ & $25.0 \%$ \\
Schizophrenia & $\mathrm{N}=48$ & $6.3 \%$ & $47.9 \%$ \\
Control & $\mathrm{N}=48$ & $6.3 \%$ & $39.6 \%$ \\
\hline
\end{tabular}

${ }^{*} \mathrm{p}<.05$ (Fisher's test) phisms for DRD2 and DRD3 and its synthesizing enzyme (TH).

DRD2 Ser311Cys. Arinami et al. (1994) were the first to report that the allele frequency of the 311Cys of the DRD2 gene was about three times higher in Japanese schizophrenics than in control subjects. These authors have since duplicated their own results in a larger population study (Arinami et al. 1996), in which it was shown that the clinical characteristics of schizophrenic patients with the 311Cys gene were lacking negative symptoms, going into remission and having a family history of the disorder. Many studies, however, have failed to duplicate these results in various races (Gejman et al. 1994; Nanko et al. 1994; Asherson et al. 1996; Chen et al. 1996; Sasaki et al. 1996; Spurlock et al. 1998); only one study corroborated these results (Shaikh et al. 1994). Very recently, Serretti et al. (2000) demonstrated a significant association between the Ser311Cys variant and delusional features in major psychoses (including delusional disorder and schizophrenia) in Italian patients. This indicates that this mutation may be connected with delusional symptomatology independent of diagnoses, although it does not play a major role in conferring susceptibility to major psychoses.

The results of the study presented here demonstrated that the genotype frequency of Ser311Cys of delusional disorder is about three times higher than in schizophrenic and control subjects. So far, two previous studies have shown a negative association between 
Table 3. Association between Dopamine Receptor Gene, pHVA and BPRS Score

\begin{tabular}{llcc}
\hline Receptor & \multicolumn{1}{c}{ Genotype } & pHVA (pmol/ml) & BPRS Score \\
\hline D2 & Ser311Cys $(\mathrm{N}=4)$ & $77.8 \pm 7.6$ & $7.0 \pm 0.7$ \\
& Ser311Ser $(\mathrm{N}=0)$ & $58.6 \pm 9.4$ & $6.3 \pm 0.6$ \\
$\mathrm{D} 3$ & Ser9Ser $(\mathrm{N}=5)$ & $85.6 \pm 8.1^{*}$ & $8.0 \pm 0.7^{\#}$ \\
& Ser9Gly $(\mathrm{N}=8)$ & $51.3 \pm 7.5$ & $5.6 \pm 0.3$ \\
$\mathrm{D} 2+\mathrm{D} 3$ & Ser/Cys + Ser/Ser $(\mathrm{N}=3)$ & $77.0 \pm 10.7^{*}$ & $7.3 \pm 0.8$ \\
& Ser/Cys + Ser/Gly $(\mathrm{N}=7)$ & $47.2 \pm 7.3$ & $5.6 \pm 0.4$ \\
\hline${ }^{*} \mathrm{p}<0.05$ (Student's t-test) & & \\
${ }^{\#} \mathrm{p}<0.05$ (Mann-Whitney U test) & &
\end{tabular}

DRD2 Ser311Cys and delusional disorder (Sasaki et al. 1996; Serretti et al. 2000). In these studies, different criteria (DSM) were used to diagnose the subjects, which might have resulted in the inclusion of greater numbers of paranoia and fewer paraphrenia. In addition, their neuroleptic responses were not clearly described. Rather, our subjects had neuroleptic responses similar to those of Arinami's subgroup with a high incidence of 311Cys.

Since the Ser311Cys mutation has been shown to cause functional alteration of DRD2 in vitro, such as receptor internalization (Itokawa et al. 1996) and inhibition of cAMP synthesis (Cravchik et al. 1996), dopamine signal transmission may be increased in delusional patients with this mutation.

DRD3 Ser9Gly. After the first demonstration that homozygous Ser9Ser of the DRD3 gene was significantly higher in patients with schizophrenia by Crocq et al. (1992), several studies, which focused especially on the schizophrenics who were good neuroleptic responders, have been able to duplicate it (Jonsson et al. 1993; Mant et al. 1994; Nimgaonkar et al. 1996; Shaikh et al. 1996; Spurlock et al. 1998), but many other studies have failed (see review of Dubertret et al. (1998) and Williams et al. (1998)). Two recent meta-analysis studies have demonstrated a slight but significant excess of homozygous Ser9Ser in all schizophrenic patients (Williams et al. 1998), or only in the African and Caucasian groups (Dubertret et al. 1998). On the other hand, in delusional disorder, a significant association with Ser9Ser was reported (Di Bella et al. 1994).

Our findings on persecution-type delusional patients are similar to those of Di Bella, although they were not statistically significant because of the small population

Table 4. Association between the Polymorphic (TCAT)n Repeat of TH Gene and Pretreatment Levels of pHVA

\begin{tabular}{cc}
\hline \multicolumn{1}{c}{ Genotype } & $\begin{array}{c}\text { pHVA } \\
(\mathbf{p m o l} / \mathbf{m l})\end{array}$ \\
\hline$(\mathrm{TCAT})_{9}{ }^{*}(\mathrm{TCAT})_{6}$ or $(\mathrm{TCAT})_{9}{ }^{*}(\mathrm{TCAT})_{7}(\mathrm{n}=7)$ & $47.9 \pm 7.9$ \\
$(\mathrm{TCAT})_{9}{ }^{*}(\mathrm{TCAT})_{8}$ or $(\mathrm{TCAT})_{9}{ }^{*}(\mathrm{TCAT})_{9}(\mathrm{n}=4)$ & $87.1 \pm 8.1^{*}$ \\
\hline${ }^{*} \mathrm{p}<.05$ (Student's t-test $)$ &
\end{tabular}

used. More importantly, in our results it appeared that the pretreatment level of pHVA was higher in patients with Ser9Ser than those with Ser9Gly. Normal homozygous control subjects also appeared to have a higher CSF HVA level (Jonsson et al. 1996). Furthermore, in a previous in vitro study it was reported that the binding activity of DRD3 homozygous for Ser9Ser is lower (Lundstrom and Turpin 1996).

It has been shown that DRD3 is localized in the limbic brain as autoreceptors regulating pre-synaptic dopamine release (Sokoloff et al. 1990). In delusional disorder, the DRD3 gene homozygous for Ser9Ser may be one of the etiologic genes responsible for producing the high pHVA levels observed in our study, which causes paranoid symptoms.

TH VNTR. It has been reported previously that polymorphism of TH gene VNTR is related to transcription in vitro (Meloni et al. 1998) and to catecholamine turnover in vivo (Wei et al. 1997). Several studies on schizophrenia have indicated a significant association with the polymorphic VNTR region of the TH gene (Thibaut et al. 1997; Wei et al. 1997). Consistent with these results, our findings in delusional patients demonstrated that the pretreatment level of pHVA is significantly correlated to the VNTR $(\mathrm{TCNT})_{\mathrm{n}}$ repeat, suggesting that TH VNTR is another etiologic candidate gene for the high pHVA level.

Although further studies on a large sample size are required to confirm our tentative results, polygenes of both the pre- and post-synaptic mechanisms of dopamine systems may be involved in the genetic etiology of delusional disorder, especially in the persecution-type.

\section{REFERENCES}

American Psychiatric Association (1994): DSM-IV. Diagnostic and Statistical Manual of Mental Disorders. 4th edition, APA, Washington, DC.

Arinami T, Itokawa M, Enguchi H, Tagaya H, Yano S, Shimizu $H$ (1994): Association of dopamine D2 receptor molecular variant with schizophrenia. Lancet 343:703-704

Arinami T, Itokawa M, Aoki J, Shibuya H, Ookubo Y, Iwawaki A, Ota K (1996): Further association study on 
dopamine D2 receptor variant S311C in schizophrenia and affective disorder. Am J Med Genet 67:133-138

Asherson P, Williams N, Roberts E, McGuffin M, Owen M (1996): DRD2 Ser311/cys311 polymorphism in schizophrenia. Lancet 343:1045

Bowers MB Jr, Swigar M, Jatlow P, Goicoechea N (1984): Plasma Catecholamine metabolites and early response to haloperidol. J Clin Psychiatry 45: 248-251

Bowers MB Jr (1993): Psychotic patients with increased plasma HVA and MHPG or increased HVA alone. Biol Psychiatry 34:584-586

Breier A, Su TP, Saunders R, Carson RE, Kolachana BS, de Bartolomeis A, Weinberger DR, Weisenfeld N, Malhotra AK, Eckelman WC, Pickar D (1997): Schizophrenia is associated with elevated amphetamine-induced synaptic dopamine concentrations: evidence from a novel positron emission tomography method. Proc Natl Acad Sci USA 94:2569-2574

Carlsson A (1988): The current status of the dopamine hypothesis of schizophrenia. Neuropsychopharmacology 1:179-186

Carpenter WTJ, Heinrichs DW, Wagman AM (1988): Deficit and nondeficit forms of schizophrenia: The concept. Am J Psychiatry 145:578-583

Chang WH, Scheinin MD, Burns RS, Linnoila MD (1983): Rapid and simple determination of homovanillic acid in plasma using high performance liquid chromatography with electrochemical detection. Acta Pharmacol Toxicol 53:275-279

Chang W, Chen T, Lee C, Hung J, Hu W, Yeh E (1988): Plasma homovanillic acid levels and subtyping of schizophrenia. Psychiatry Res 23:239-244

Chen CH, Chien SH, Hwu HG (1996): No association of dopamine D2 receptor molecular variant Cys311 and schizophrenia on Chinese patients. Am J Med Genet 67: 418-420

Cravchik A, Sibley DR, Gejman PV (1996): Functional analysis of the human D2 dopamine receptor missense variants. J Biol Chem 42:26013-26017

Crocq MA, Mant R, Asherson P, Williams J, Hode Y, Mayerova A, Collier D, Lannfelt L, Sokoloff P, Schwartz JC (1992): Association between schizophrenia and homozygosity at the dopamine D3 receptor gene. J Med Genet 29:858-860

Crow TJ (1980): Molecular pathology of schizophrenia: more than one disease process? BMJ 280:66-68

Davidson M, Davis KL (1988): A comparison of plasma homovanillic acid concentrations in schizophrenic patients and normal controls. Arch Gen Psychiatry 45:561-563

Davis KL, Davidson M, Mohs RC, Kendler KS, Davi BM, Johns CA, DeNigris Y, Horvath TB (1985): Plasma homovanillic acid concentration and the severity of schizophrenia illness. Science 29:1601-1602

Davis KL, Kahn RS, Ko G, Davidson M (1991): Dopamine in schizophrenia: A review and reconceptualization. Am J Psychiatry 148:1474-1486

Di Bella D, Catalano M, Strukel A, Nobile M, Novelli E, Smeraldi E (1994): Distribution of Mscl polymorphism of the dopamine D3 receptor in an Italian psychotic population. Psychiatr Genet 4:39-42

Dubertret C, Gorwood P, Ades J, Feingold J, Schwartz JC,
Sokoloff P (1998): Meta-analysis of DRD3 gene and schizophrenia: ethnic heterogeneity and significant association in Caucasians. Am J Med Genet 10:318-322

Ellinwood EH (1976): Amphetamine psychosis I. Description of the individuals and process. J Nerv Ment Dis 144:273-283

Fujinawa A (1981): The paranoid symptoms which appear in the latter half of life. Clin Psychopathology 2:7-19

Garver DL, Steinberg JL, McDermott BE, Yao JK, Ramberg JE, Lewis S, Kingsbury SJ (1997): Etiologic heterogeneity of the psychoses: is there a dopamine psychosis? Neuropsychopharmacology 14:191-201

Gejman PV, Ram A, Gelernter J, Friedman E, Cao Q, Pickar D, Blum K, Noble EP, Kranzler HR, O'malley S (1994): No structural mutation in dopamine D2 receptor gene in alcoholism or schizophrenia. JAMA 271:204-208

Harrison PJ (1999): The neuropathology of schizophrenia: a critical review of the data and their interpretation. Brain 122:593-624

Itokawa M, Toru M, Ito K, Tsuga H, Kameyama K, Haga T, Arinami T (1996): Sequestration of the short and long isoforms of dopamine D2 receptors expressed in Chinese hamster ovary cells. Mol Pharmacol 49:560-566

Janowski DS, Davis JM (1976): Methylphenidate, dextroamphetamine and levamfetamine. Effects on schizophrenic symptoms. Arch Gen Psychiatry 33:304-308

Jonsson E, Annfelt L, Sokoloff P, Schwartz JC, Sedvall G (1993): Lack of association between schizophrenia and alleles in the dopamine D3 receptor gene. Acta Psychiatr Scand 87: 345-349

Jonsson E, Sedvall G, Brene S, Gustavsson JP, Geijer T, Terenius L, Crocq MA, Lannfelt L, Tylec A, Sokoloff $\mathrm{P}$, Schwartz JC, Wiesel FA (1996): Dopamine-related genes and their relationships to monoamine metabolites in CSF. Biol Psychiatry 40:1032-1044

Kalivas PW (1993): Neurotransmitter regulation of dopamine neurons in the ventral tegmental area. Brain Res Rev 18:75-113

Koreen AR, Lieberman J, Alvir J, Mayerhoff D, Loebel A, Chakos M, Amin F, Cooper T (1994): Plasma homovanillic acid levels in first episode schizophrenia. Psychopathology and treatment response. Arch Gen Psychiatry 51:132-138

Kraepelin E (1909): Psychiatrie, Achte Auflage. Leipzig, Johann Ambrosius Barth

Laruelle M, Abi-Dargham A, van Dyck CH, Gil R, D'Souza CD, Erdos J, McCance E, Rosenblatt W, Fingado C, Zoghbi SS, Baldwin RM, Seibyl JP, Krystal JH, Charney DS, Innis RB (1996): Single photon emission computerized tomography imaging of amphetamine-induced dopamine release in drug-free schizophrenic subjects. Proc Natl Acad Sci USA 93:9235-9240

Laruelle M (1998): Imaging dopamine transmission in schizophrenia. A review and meta-analysis. Q J Nucl Med 42:211-221

Liddle PF (1987): The symptoms of schizophrenia. A reexamination of positive-negative dichotomy. Br J Psychiatry 151:145-151

Lieberman JA, Kane JM, Alvir J (1987): Provocative tests with psychostimulant drugs in schizophrenia. Psychopharmacology (Berl) 91:415-433

Lundstrom K, Turpin MP (1996): Proposed schizophrenia- 
related gene polymorphism: Expression of the Ser9Gly mutant human dopamine D3 receptor with the semliki forest virus system. Biochem Biophy Res Comm 225: 1068-1072

Mant R, Williams J, Asherson P, Parfitt E, McGuffin P, Owen MJ (1994): Relationship between homozygosity at the dopamine D3 receptor gene and schizophrenia. Am J Med Genet 54:21-26

Meloni R, Albanese V, Ravassard P, Treihou F, Mallet J (1998): A tetranucleotide polymorphic microsatellite, located in the first intron of the tyrosine hydroxylase gene, acts as a transcription regulatory element in vitro. Hum Mol Genet 7:423-428

Munro A, Mok H (1995): An overview of treatment in paranoia/delusional disorder. Can J Psychiatry 40:616-622

Nagaoka S, Iwamaoto N, Arai H (1997): First-episode neuroleptic-free schizophrenics: Concentrations of monoamines and their metabolites in plasma and their correlations with clinical responses to haloperidol treatment. Biol Psychiatry 41:857-864

Nanko S, Hattori M, Dai XY, Fukuda R, Sasaki T, Kazamatsuri H (1994): DRD2 Ser311/Cys311 polymorphism in schizophrenia. Lancet 343:1044

Nimgaonkar VL, Sanders AR, Ganguli R, Zhang XR, Brar J, Hogge W, Fann WE, Patel PI, Chakravarti A (1996): Association study of schizophrenia and the dopamine D3 receptor gene locus in two independent samples. Am J Med Genet 67:505-514

Ottong SE, Garver DL (1997): A biomodal distribution of plasma HVA/MHPG in the psychoses. Psychiatry Res 69:97-103

Pearlson GD, Kreger L, Rabins PV, Chase GA, Cohen B, Wirth JB, Schlaepfer TB, Tune LE (1989): A chart review study of late-onset and early-onset schizophrenia. Am J Psychiatry 146:1568-1574

Pickar D, Labarca R, Linnoila M, Roy A, Hommer D, Everett D, Paul SM (1984): Neuroleptic-induced decrease in plasma homovanillic acid and antipsychotic activity in schizophrenic patients. Science 225:954-957

Pickar D, Labarca R, Doran AR, Wolkowitz OM, Roy A, Bteier A, Linnoila M, Paul SM (1986): Longitudinal measurement of plasma homovanillic acid levels in schizophrenic patients. Correlation with psychosis and response to neuroleptic treatment. Arch Gen Psychiatry 43:669-676

Ribeyre J-M, Lesieur P, Varoquaux O, Dollfus S, Pay M, Petit M (1994): A comparison of plasma homovanillic acid in the deficit and nondeficit subtypes of schizophrenia. Biol Psychiatry 36:230-236

Roth M (1987): Late paraphrenia. In Miller NE, Cohen GE, (eds), Schizophrenia and Aging. New York: Guilford, pp 217-234

Sasaki T, Macciardi FM, Badri F, Verga M, Melzer HY, Lieberman J, Howard A, Bean G, Joffe RT, Hudson CJ, Kennedy JL (1996): No evidence for association of dopamine D2 receptor variant (Ser311/Cys 311) with major psychosis. Am J Med Genet 67:415-417

Sato M, Numachi Y, Hamamura T (1992): Relapse of paranoid psychotic state in methamphetamine model of schizophrenia. Schizophr Bull 18:115-122

Seeman P, Lee T, Chau-Wong M, Wong K (1976): Antipsychotic drug dose and neuroleptics/dopamine receptors. Nature 261:717-719
Serretti A, Latuada E, Lorenzi R, Lilli R, Smeraldi E (2000): Dopamine receptor D2 Ser/Cys311 is associated with delusion and disorganization symptomatology in major psychoses. Mol Psychiatry 5:270-274

Shaikh S, Collier D, Arranz M, Ball D, Gill M, Kerwin R (1994): DRD2 Ser311/cys311 polymorphism in schizophrenia. Lancet 343:1045-1046

Shaikh S, Collier DA, Sham PC, Ball D, Aitchison K, Vallada H, Smith I, Gill M, Kerwin RW (1996): Allelic association between a Ser-9-Gly polymorphism in the dopamine D3 receptor gene and schizophrenia. Hum Genet 97: 714-719

Soares JC, Innis RB (1999): Neurochemical brain imaging investigations of schizophrenia. Biol Psychiatry 46:600-615

Sokoloff P, Giros B, Martres MP, Bouthenet ML, Schwartz JC (1990): Molecular cloning and characterization of a novel dopamine receptor (D3) as a target for neuroleptics. Nature 347:146-151

Spurlock G, Williams J, McGuffin P, Aschauer HN, Lenzinger E, Fuchs K, Sieghart WC, Meszaros K, Fathi N, Laurent C, Mallet J, Macciardi F, Pedrini S, Gill M, Hawi Z, Gibson S, Jazin EE, Yang HT, Adolfsson R, Pato CN, Dourado AM, Owen MJ (1998): European multicentre association study of schizophrenia: A study of the DRD2 Ser311Cys and DRD3 Ser9Gly polymorphisms. Am J Med Genet 81:24-28

Thibaut F, Ribeyre JM, Dourmap N, Meloni R, Laurent C, Campion D, Menard JF, Dollfus S, Mallet J, Petit M (1997): Association of DNA polymorphism in the first intron of the tyrosine hydroxylase gene with disturbances of the catecholaminergic system in schizophrenia. Schizophr Res 23:259-264

Thibaut F, Ribeyre JM, Dourmap N, Menard JF, Dollfus S, Petit M (1998): Plasma 3-methoxy-4-hydroxyphenylglycol and homovanillic acid measurements in deficit and nondeficit forms of schizophrenia. Biol Psychiatry 43:24-30

Wei J, Ramchand CN, Hemmings GP (1995): Association of polymorphic VNTR region in the first intron of the human Th gene with disturbances of the catecholamine pathway in schizophrenia. Psychiat Genet 5:83-88

Wei J, Ramchand CN, Hemmings G (1997): Possible association of catecholamine turnover with polymorphic (TCAT)n repeat in the first intron of the human tyrosine hydroxylase gene. Life Sci 61:1341-1347

WHO (1992): The ICD-10 Classification of Mental and Behavioural Disorders: Clinical Description and Diagnostic Guidelines. Geneva, WHO

Williams J, Spurlock G, Holmans P, Mant R, Murphy K, Jones L, Cardno A, Asherson P, Blackwood D, Muir W, Meszaros K, Aschauer H, Mallet J, Laurent C, Pekkarinen P, Seppala J, Stefanis CN, Papadimitriou GN, Macciardi F, Verga M, Pato C, Azevedo H, Crocq MA, Gurling H, Owen MJ (1998): A meta-analysis and transmission disequilibrium study of association between the dopamine D3 receptor gene and schizophrenia. Mol Psychiatry 3:141-149

Willner P (1997): The dopamine hypothesis of schizophrenia: current status, future prospects. Intl Clin Psychopharmacol 12:297-308

Zakzanis KK, Hansen KT, Liddle PF, Barnes TR (1998): Dopamine D2 densities and the schizophrenic brain. Schizophrenia Res 32:201-206 